\title{
Effect of Carbonic Anhydrase on $\mathrm{CaCO}_{3}$ Crystallization in Alkaline Solution
}

\author{
Murat Molva, Sevgi Kilic, and Ekrem Ozdemir* \\ Department of Chemical Engineering, Izmir Institute of Technology, Gulbahce Campus, 35430, Urla, Izmir, Turkey
}

ABSTRACT: The effect of bovine carbonic anhydrase (CA) on calcium carbonate $\left(\mathrm{CaCO}_{3}\right)$ crystallization was investigated. A new method was developed to estimate the biocatalytic activity of CA in alkaline solution. The CA was immobilized within polyurethane (PU) foam, and compared its biocatalytic activity with the free-CA and bare-PU foam. A minireactor was created in a calcium hydroxide $\left(\mathrm{Ca}(\mathrm{OH})_{2}\right)$ solution in order to control the $\mathrm{CO}_{2}$ transfer rate, and reproducible results were obtained. It was found that the free-CA lost its activity in less than $6 \mathrm{~min}$ at $\mathrm{pH} 12.5$ in alkaline $\mathrm{Ca}(\mathrm{OH})_{2}$ solution. The $\mathrm{CaCO}_{3} \mathrm{crystallization}$ rates for the immobilized-CA were found to be a U-shape, relatively lower at lower immobilized-CA amounts compared to those for the free-CA and bare-PU foam and higher when the amount of immobilized-CA increased. It was concluded that a higher immobilized-CA amount is required to accelerate the $\mathrm{CaCO}_{3}$ crystallization rates in $\mathrm{Ca}(\mathrm{OH})_{2}$ solution.

\section{INTRODUCTION}

Atmospheric concentration of carbon dioxide $\left(\mathrm{CO}_{2}\right)$ has been increasing due to anthropogenic activities. ${ }^{1}$ In order to control the $\mathrm{CO}_{2}$ concentration in the atmosphere, a number of $\mathrm{CO}_{2}$ sequestration options have been proposed such as storing $\mathrm{CO}_{2}$ in geological formations including unmineable coal seams, saline aquifers, abandoned gas and oil reservoirs, injection of $\mathrm{CO}_{2}$ in the ocean, enhancement of $\mathrm{CO}_{2}$ consumption by a terrestrial ecosystem, and conversion of $\mathrm{CO}_{2}$ by advanced chemical and biological methods into more useful and value added products. $^{2}$ In these sequestration options, however, the $\mathrm{CO}_{2}$ needs to be pure for which the $\mathrm{CO}_{2}$ is captured from the flue gases, compressed to the desired pressures, transported to a sequestration site, and, finally, injected within the sequestration area for long-term storage. ${ }^{3}$ All of these processes increase the sequestration cost. ${ }^{4,5}$ The sequestration cost could be reduced if the $\mathrm{CO}_{2}$ is captured and sequestered directly at the production sites. Moreover, the production of valuable products from $\mathrm{CO}_{2}$, such as nanosized calcium carbonate $\left(\mathrm{CaCO}_{3}\right)$, which is extensively used as filling material or pigment in paper, paints, and plastics industries, could make the sequestration process economically feasible. ${ }^{7,8}$ However, the hydration of the $\mathrm{CO}_{2}$ is the slowest step. ${ }^{9}$

Attempts have been made to enhance the hydration of $\mathrm{CO}_{2}$ in the presence of a biocatalyst, carbonic anhydrase (CA)..$^{10-12}$ Bond et al. ${ }^{13}$ developed an integrated system for biomimetic $\mathrm{CO}_{2}$ sequestration, employing the $\mathrm{CA}$ enzyme to accelerate the rate of $\mathrm{CO}_{2}$ hydration for the subsequent fixation into stable mineral carbonates utilizing artificial seawater. Sharma et al. ${ }^{14}$ isolated CA from different sources of bacteria and employed for $\mathrm{CO}_{2}$ sequestration into $\mathrm{CaCO}_{3}$. Favre et al. ${ }^{15}$ reported an acceleration of $\mathrm{CaCO}_{3}$ crystallization in the presence of $\mathrm{CA}$ enzyme. $\mathrm{Li}$ et al. ${ }^{16-20}$ reported the effects of CA on the $\mathrm{CaCO}_{3}$ crystallization with particle sizes larger than $20 \mu \mathrm{m}$. Mirjafari et al. ${ }^{12}$ investigated the effect of $\mathrm{CA}$ on enhancement of $\mathrm{CO}_{2}$ hydration in the solution. Liu et al. ${ }^{11}$ studied the precipitation of $\mathrm{CaCO}_{3}$ from produced waters in the presence of CA. There are some disadvantages of using the free enzyme in solution such that the stability of the enzyme is low, its repeatable usage is limited, and its recovery from the reaction environment generally is not possible. These disadvantages can be eliminated by immobilizing the enzyme within or onto some solid and polymeric supports. Carbonic anhydrase has been immobilized on solid supports by different forms of attachments. For example, Drevon et al. ${ }^{21}$ immobilized carbonic anhydrase in coatings by covalent bonding; Liu et al. ${ }^{11}$ immobilized CA on chitosan-alginate beads by encapsulation; Jovica and Kostic ${ }^{22}$ immobilized CA within silica monoliths by a sol-gel method; Cheng et al. ${ }^{23}$ immobilized CA within the poly(acrylic acid-coacrylamide) hydrogel by entrapment; and Hosseinkhani and Gorgani $^{24}$ immobilized CA on hydrophobic adsorbent of Sepharose $4 \mathrm{~B}$ by adsorption. Although polyurethanes (PU) are widely used supports for immobilization of enzymes and cells, $^{25-29}$ the bovine carbonic anhydrase (CA) has not been immobilized within PU-foam, to our knowledge, for the first time, the CA enzyme was immobilized within PU foam by cross-linking in our lab. ${ }^{30,31}$ Since then, the $\mathrm{CO}_{2}$ sequestration efficiency of the immobilized CA has not been investigated especially in alkaline conditions.

An accurate measurement method is needed to measure the biomimetic CA activity in alkaline conditions. Three types of experimental techniques have been developed to measure the $\mathrm{CA}$ activity such as the electrochemical method or $\mathrm{pH}$-drift method, ${ }^{12,13,32,33}$ manometric method, ${ }^{34,35}$ and colorimetric method. $^{31,36}$ There are advantages and disadvantages for each technique. While the electrochemical and manometric techniques employ $\mathrm{CO}_{2}$ as the substrate, the colorimetric technique uses an organic ester as the substrate. In the $\mathrm{pH}$-drift method, it is needed to measure precisely the time to reduce the $\mathrm{pH}$ from about 7.5 to 5.5 in the presence of enzyme. Lower temperatures, to about $0-5{ }^{\circ} \mathrm{C}$, are required to slow down the $\mathrm{CA}$ activity. Also, a high precision $\mathrm{pH}$ electrode and a very fast $\mathrm{pH}$ measurement system are needed for accuracy. ${ }^{12}$ Therefore,

Received: September 25, 2016

Revised: October 28, 2016

Published: November 8, 2016 
it is hard to measure the CA enzyme activity or the initial rate at alkaline conditions and false results could be obtained. ${ }^{12,13,37-39}$ For instance, after measuring the CA activity by the $\mathrm{pH}$-drift method, Bond et al. ${ }^{13}$ reported that the $\mathrm{SO}_{4}{ }^{2-}$ ion, one of the major components in flue gas, is an inhibitor to CA. However, after measuring the CA activity by the colorimetric method, Ramanan et al. ${ }^{40}$ reported a contradictory result showing that the $\mathrm{SO}_{4}{ }^{2-}$ ion indeed enhances the $\mathrm{CA}$ activity of about $26 \%$. In the manometric technique, the gas pressure change is measured on the top of the enzyme solution with time; therefore, it can be called a pressure-drift method. The rate of $\mathrm{CO}_{2}$ absorption into the solution was used as an indication of the $\mathrm{CA}$ activity for $\mathrm{CO}_{2}$ hydration. ${ }^{34}$ However, the volume of the gas on the liquid, the gas-liquid interface area, and temperature need to be determined accurately and the mass balance needs to account for the compressibility factor $(z)$ at higher temperatures and pressures. ${ }^{41}$ Therefore, the pressuredrift method need improvements. The most comparable results for the CA activity were reported with the colorimetric technique in the literature. In the colorimetric method, paranitrophenyl acetate ( $p-\mathrm{NPA})$, an ester, was used as the substrate and the hydrolysis activity of CA is determined. One of the hydrolysis products is para-nitrophenol ( $p$-NP), and the hydrolysis reaction can be followed easily by measuring UVvisible absorption at a wavelength of $400 \mathrm{~nm}$ for $p$-NP. However, $p$-NPA is not soluble in water and acetonitrile is used as a solvent. Therefore, the activity assay contains $10 \%$ of acetonitrile, which was shown to inhibit the CA activity. ${ }^{30}$ Also, $p$-NPA undergoes self-dissociation exponentially with $\mathrm{pH}$ and temperature and almost linearly with its concentration. Thus, accurate corrections are needed for the determination of the CA activity for the colorimetric method. Another drawback in the colorimetric method is that the CA activity is measured with a chemical molecule, $p$-NPA, instead of $\mathrm{CO}_{2}$ itself. Therefore, a new measurement method is needed to measure the biomimetic CA activity for $\mathrm{CO}_{2}$, especially in alkaline conditions.

We have recently reported that, in a calcium hydroxide $\left(\mathrm{Ca}(\mathrm{OH})_{2}\right)$ solution, the conductivity values are linearly related to the $\mathrm{Ca}(\mathrm{OH})_{2}$ concentrations up to its solubility limit of about $20 \mathrm{mM}$, and therefore, the crystallization rate can be estimated from the conductivity changes in the $\mathrm{Ca}(\mathrm{OH})_{2}$ solution. ${ }^{6,42}$ Here, a new method was developed to measure the immobilized CA enzyme activity in alkaline solution for the biomimetic $\mathrm{CO}_{2}$ sequestration into inorganic $\mathrm{CaCO}_{3}$.

\section{MATERIALS AND METHODS}

2.1. Materials. Carbonic anhydrase from bovine erythrocytes (BCA) (MW: $29000,89 \%$ pure in protein as dialyzed and lyophilized powder) was purchased from Sigma-Aldrich. Calcium hydroxide $\left(\mathrm{Ca}(\mathrm{OH})_{2}\right)$, sodium hydroxide $(\mathrm{NaOH}, 97 \% \mathrm{w} / \mathrm{w})$, and hydrochloric acid $(35 \% \mathrm{v} / \mathrm{v})$ were all purchased from Merck and used without further purifications. Carbon dioxide $\left(\mathrm{CO}_{2}\right)$ was purchased from Carbogas Co., Turkey, with a purity of $99.99 \%$. Polyurethane prepolymer, HYPOL-2060, was provided as a kind gift from Dow Chemical Co., Turkey.

2.2. Experimental Setup. An experimental setup was designed for the measurement of CA enzyme activity in alkaline solution as shown in Figure 1. The reactor was a three-neck round-bottom flask. A glass $\mathrm{pH}$ probe (Orion), a conductivity cell (Orion), and a glass tubing with a diameter of $5 \mathrm{~mm}$ were attached on each port and sealed gastight with a rubber gasket. A $20 \mathrm{mM} \mathrm{Ca}(\mathrm{OH})_{2}$ solution was prepared in the flask by dissolving $0.3 \mathrm{~g}$ of $\mathrm{Ca}(\mathrm{OH})_{2}$ powder in $200 \mathrm{~mL}$ of ultrapure water (Millipore Elix-5/Milli-Q). A plastic balloon was used in the

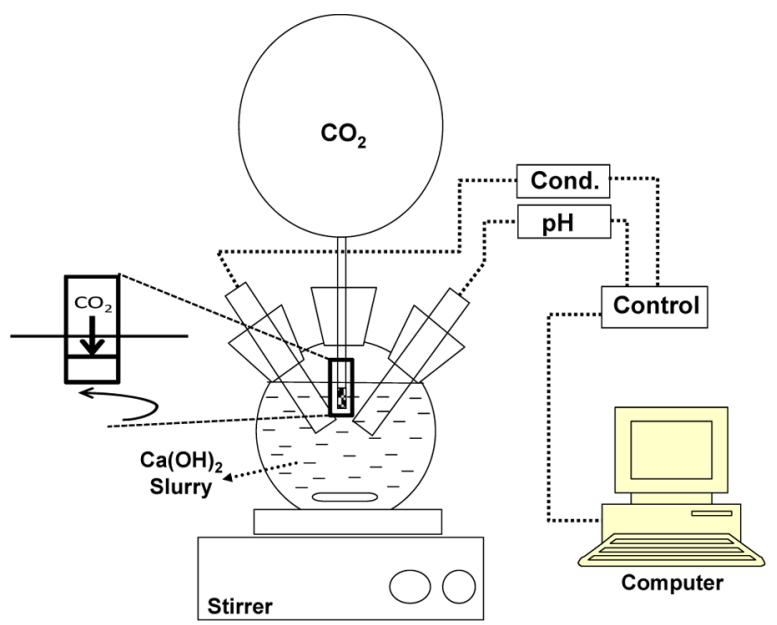

Figure 1. Experimental setup for biomimetic $\mathrm{CaCO}_{3}$ carbonization.

experimental setup in order not to disturb the gas-liquid interface and not to cause pressure anomalies as occurring in the manometric method. The plastic balloon filled with $\mathrm{CO}_{2}$ was attached to the top of the glass tubing, which was immersed into the $\mathrm{Ca}(\mathrm{OH})_{2}$ solution. Therefore, a minireactor with a diameter of $5 \mathrm{~mm}$ and a height of about $1 \mathrm{~cm}$ was created on the surface of the $\mathrm{Ca}(\mathrm{OH})_{2}$ solution for $\mathrm{CO}_{2}$ dissolution. As can be seen in the figure, $\mathrm{CO}_{2}$ was allowed first to dissolve on the surface of the solution within the minireactor and diffuse into the stirred bulk solution. The $\mathrm{CO}_{2}$ bubbling was not allowed to happen during the injection. Batch experiments were conducted at room temperature at $600 \mathrm{rpm}$ of stirring. The conductivity probe was calibrated against its standard solution before each experiment. All data were collected online by a PC with a 5-Star Navigator software program. Precipitation was terminated when the $\mathrm{pH}$ reached to about 7 during crystallization.

2.3. $\mathrm{CaCO}_{3}$ Synthesis with Polyurethane Foam. In order to compare the effect of immobilized-CA enzyme on the $\mathrm{CaCO}_{3}$ crystallization, control experiments were conducted by using bare polyurethane (PU) foams. Production of PU-foam was reported previously. ${ }^{30,31}$ Briefly, about $3.5 \mathrm{~g}$ of prepolymer, HYPOL2060, was mixed with an equal amount of water. The two-phase system was mixed vigorously for $30 \mathrm{~s}$ by a drill with a handmade mixer blade. The level of the white polymeric solution started to increase as a result of a $\mathrm{CO}_{2}$ release during the polymerization. The level, and thus the polymerization, settled in 2-3 min. Polymerization was carried out at room temperature. After polymerization, the foam was allowed to cure for at least $2 \mathrm{~h}$ prior to its use. In order to be able to mix the foams within the $20 \mathrm{mM} \mathrm{Ca}(\mathrm{OH})_{2}$ solution, the foam was cut into very small pieces of about $2 \mathrm{~mm} \times 2 \mathrm{~mm} \times 2 \mathrm{~mm}$ by scissors. Otherwise, PUfoam with bigger sizes was seen to float on the surface of the solution. Different amounts of foam pieces were used in the experiments.

2.4. $\mathrm{CaCO}_{3}$ Synthesis with Free-CA. $\mathrm{CaCO}_{3}$ crystallization was investigated in the presence of free carbonic anhydrase. A $12.55 \mathrm{mg}$ portion of CA enzyme was dissolved in $6 \mathrm{~mL}$ of ultrapure water by stirring at $600 \mathrm{rpm}$ on a magnetic stir plate to prepare a stock solution of the enzyme. A $250 \mu \mathrm{L}$ aliquot of free-CA enzyme from its stock solution was added into the $\mathrm{Ca}(\mathrm{OH})_{2}$ solution, and the mixture was stirred for an additional $5 \mathrm{~min}$ at $600 \mathrm{rpm}$ before injection of $\mathrm{CO}_{2}$. In this case, the concentration of the free-CA was calculated to be 0.09 $\mu \mathrm{M}$. Similar to Mirjafari et al., ${ }^{12}$ up to $2.0 \mathrm{~mL}(0.71 \mu \mathrm{M})$ of free-CA enzyme was used in the crystallization experiments.

2.5. $\mathrm{CaCO}_{3}$ Synthesis with Immobilized-CA. The procedures for immobilization and characterization of the immobilized-CA enzyme within PU foam have been reported previously. ${ }^{30,31}$ Briefly, immobilization occurs covalently via isocyanate groups on the prepolymer and amine groups on the enzyme. A predetermined amount of CA enzyme in powder form was dissolved in $3 \mathrm{~mL}$ of ultrapure water, and the resulting solution was poured onto about $3 \mathrm{~g}$ of viscous HYPOL2060 prepolymer in a $50 \mathrm{~mL}$ falcon tube. The two- 

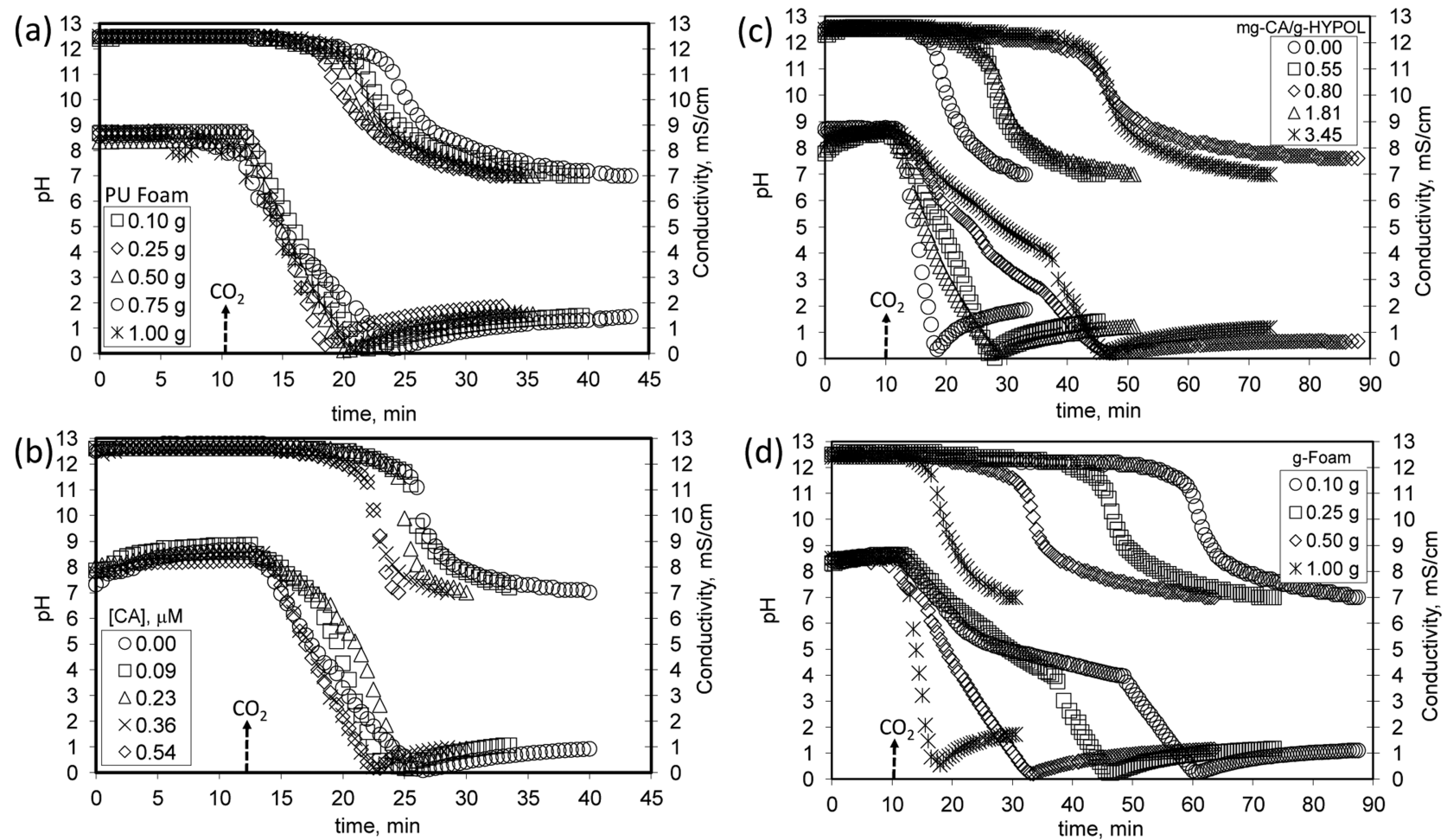

Figure 2. $\mathrm{pH}$ and conductivity values in the presence of (a) bare-PU foam, (b) free-CA, (c) $0.25 \mathrm{~g}$ of PU foam with different amounts of immobilized CA used, and (d) different amounts of PU foam with a fixed amount of $3.45 \mathrm{mg}$-CA/g-HYPOL immobilized.

phase system was mixed vigorously for $30 \mathrm{~s}$ by a drill with a handmade mixer blade to achieve a homogeneous distribution of the enzyme within the prepolymer. The polymerization settled in $2-3 \mathrm{~min}$ by releasing $\mathrm{CO}_{2}$. After curing at about $2 \mathrm{~h}$, the immobilized CA was characterized for enzyme activity, stability, and reusability. ${ }^{30,31}$ For the $\mathrm{CaCO}_{3}$ crystallization, the CA-immobilized foam was cut into small pieces of about $2 \mathrm{~mm}^{3}$ in order to suspend them within the $\mathrm{Ca}(\mathrm{OH})_{2}$ solution. Different amounts of CA-immobilized foams were used in the precipitation experiments.

2.6. Sample Characterization. After $\mathrm{CaCO}_{3}$ precipitation was completed when the $\mathrm{pH}$ value dropped to about 7 , the suspensions were taken in $50 \mathrm{~mL}$ falcon tubes and centrifuged for $10 \mathrm{~min}$ at 9000 rpm (Universal 320 - Hettich Zentrifugen). The precipitates were collected and washed with acetone and then ultrapure water. All samples were dried in an oven at $103{ }^{\circ} \mathrm{C}$ (Nüve FN 500) overnight before characterization. The morphology of the $\mathrm{CaCO}_{3}$ crystals was analyzed using a scanning electron microscope (SEM) fitted with a field emission source (Philips XL $30 \mathrm{~S}$ FEG), operating at an accelerating voltage of $15 \mathrm{kV}$. The X-ray powder diffraction (XRD) measurements were carried out using a modified computer-controlled Philips X'Pert Pro X-ray diffractometer. The crystal structure was determined using $\mathrm{Cu} \mathrm{K} \alpha$ radiation ( $45 \mathrm{kV}$ and $40 \mathrm{~mA}$ ) equipped with a diffracted-beam monochromator - accelerating detector. The fine powder was packed into a zero background sample holder. The packed powder was introduced to the detector as received. The weight of the loaded sample was not important and varied. The diffraction pattern was recorded for $2 \theta$ from $10^{\circ}$ to $80^{\circ}$, and a $2 \theta$ step scan of $0.033^{\circ}$ was used, counting for $10.16 \mathrm{~s}$ at every step. X-ray patterns were also used to determine crystal size from the broadening of the diffraction line at half the line of maximum intensity by using the Scherrer equation.

\section{RESULTS AND DISCUSSION}

In order to compare the activity of immobilized-CA in alkaline conditions, control experiments were conducted initially by using bare-PU foams. Small PU foam cubes with sizes of about $2 \mathrm{~mm}$ were dispersed in the $\mathrm{Ca}(\mathrm{OH})_{2}$ solution at a concentration of $20 \mathrm{mM}$. The $\mathrm{CO}_{2}$ dissolution and $\mathrm{CaCO}_{3}$ crystallization started when $\mathrm{CO}_{2}$ gas was released from the balloon container onto the minireactor within the $\mathrm{Ca}(\mathrm{OH})_{2}$ solution as shown in Figure 1. Any pressure fluctuations and disturbances on the gas-liquid interface were avoided by using the balloon. Both $\mathrm{pH}$ and conductivity values were monitored and recorded for evaluations. The PU foam is highly porous with pore sizes of about more than $500 \mu \mathrm{m}$ as evidenced from their SEM images. ${ }^{30,31}$ Figure $2 \mathrm{a}$ shows the $\mathrm{pH}$ and conductivity values during $\mathrm{CO}_{2}$ dissolution and $\mathrm{CaCO}_{3}$ crystallization in the presence of different amounts of barePU foams. As shown in the figure, the conductivity values decreased almost linearly for each PU foam. The time required to complete the $\mathrm{CaCO}_{3}$ crystallization was about $10 \mathrm{~min}$ and similar for different amounts of PU foams. Conductivity close to zero indicated that all $\mathrm{Ca}^{2+}$ ions were consumed in the suspension, ${ }^{6}$ at which $\mathrm{pH}$ decreased from 12.5 to about 9.5 . The solution is now called "suspension" because $\mathrm{CaCO}_{3}$ produced is in solid form suspended in the liquid phase as nanoparticles. With further dissolution of $\mathrm{CO}_{2}$, nano- $\mathrm{CaCO}_{3}$ particles were expected to dissolve, adding some $\mathrm{Ca}^{2+}$ ions back in the solution. Thus, the small increase in conductivity can be attributed to the dissolution of $\mathrm{CaCO}_{3}$ and the increase in $\mathrm{Ca}^{2+}$ concentration in the suspension. Similar completion times in $\mathrm{CaCO}_{3}$ crystallization with different amounts of foam pieces indicate that the $\mathrm{PU}$ foam is less effective on the $\mathrm{CaCO}_{3}$ crystallization, and the experiments conducted by using the minireactor is highly reproducible.

Figure $2 \mathrm{~b}$ shows the change in $\mathrm{pH}$ and conductivity values during $\mathrm{CO}_{2}$ dissolution and $\mathrm{CaCO}_{3}$ carbonization in the presence of different concentrations of free-CA. As shown in the figure, as soon as the $\mathrm{CO}_{2}$ was introduced, the conductivity values started to decrease linearly, and in some cases, a small delay was seen. The time required to decrease the conductivity values to about zero was about $10 \mathrm{~min}$ for each free-CA 

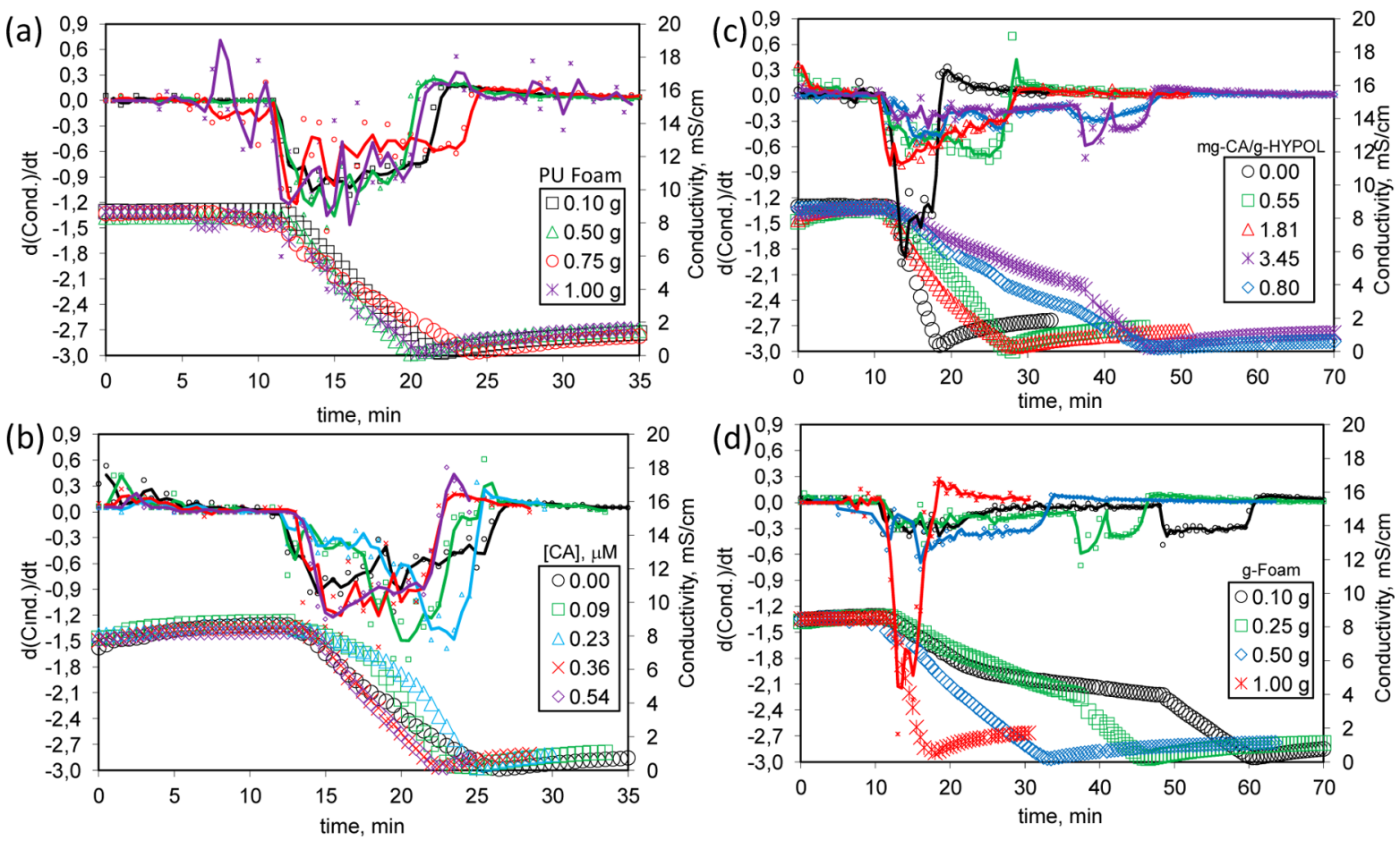

Figure 3. Rates estimated from the conductivity values in the presence of (a) bare-PU foam, (b) free-CA, (c) $0.25 \mathrm{~g}$ of PU foam with different amounts of immobilized CA used, and (d) different amounts of PU foam with a fixed amount of $3.45 \mathrm{mg}$-CA/g-HYPOL immobilized.

concentration. During this period, the $\mathrm{pH}$ decreased from 12.5 to about 9.5, similar to what was observed in the presence of PU foams. After consumption of $\mathrm{Ca}^{2+}$ ions and with further $\mathrm{CO}_{2}$ dissolution, a small increase in conductivity values was seen, indicating that the concentration of $\mathrm{Ca}^{2+}$ ions and some other ions formed from $\mathrm{CO}_{2}$ increased in the suspension. ${ }^{6}$ It is known that the stability of free- $\mathrm{CA}$ is maximum at $\mathrm{pH}$ around 8.3 , and this stability was preserved at $\mathrm{pH}$ up to 10.5 at room temperature. ${ }^{36,43}$ However, it was shown that the free-CA has lost its activity when the $\mathrm{pH}$ was $13 .^{40}$ Also, after measuring the activity of free-CA by the colorimetric method using $p$-NPA, Ramanan et al. $^{40,44}$ reported that, while the $\mathrm{Ca}^{2+}$ ion is a weak inhibitor to the free-CA, $\mathrm{HCO}_{3}{ }^{-}$and $\mathrm{CO}_{3}{ }^{2-}$ ions significantly inhibit the free-CA activity, possibly due to competition with the $p$-NPA substrate as CA catalyzes the reversible conversion of $\mathrm{HCO}_{3}{ }^{-}$to $\mathrm{CO}_{2}$. Our experimental results show that the freeCA had little or no activity on $\mathrm{CO}_{2}$ hydration or $\mathrm{CaCO}_{3}$ crystallization in high alkaline solution at $\mathrm{pH} 12.5$ even though the concentrations of free-CA varied. It is most probable that the free-CA has lost its activity at $\mathrm{pH}$ 12.5. Information is limited in the literature for the stability of free- $\mathrm{CA}$ at higher $\mathrm{pH}$ values. ${ }^{45-47}$ It may be the reason why the reports are limited on the biocatalytic activity and stability of CA at high alkaline conditions. One of the important finding of this result is that the free-CA is not active or totally inhibited in $\mathrm{Ca}(\mathrm{OH})_{2}$ solution at $\mathrm{pH} 12.5$, and therefore, the experimental procedure again is highly reproducible.

$\mathrm{We}^{30,31}$ and others ${ }^{35,36,46-48}$ have shown that biocatalytic and thermal stability of CA improved when they were immobilized. Although the free-CA has lost its activity or inhibited at high alkaline solution, the behavior of immobilizedCA has not been investigated at the indicated conditions. Here, the biocatalytic activity of immobilized-CA was studied with two-sets of experiments. First, different amounts of CA were immobilized within PU foams and only $0.25 \mathrm{~g}$ of foam samples containing different amounts of immobilized-CA was used in the $\mathrm{CO}_{2}$ hydration and $\mathrm{CaCO}_{3}$ crystallization experiments. In the second set of experiments, $3.45 \mathrm{mg}$ of CA/g of HYPOL was immobilized within PU foam and different amounts of biocatalytic-PU foam samples were used. Figure $2 \mathrm{c}, \mathrm{d}$ shows $\mathrm{pH}$ and conductivity values for $0.25 \mathrm{~g}$ of $\mathrm{PU}$ samples containing different amounts of immobilized-CA and different amounts of biocatalytic-PU foams containing the same amount of immobilized-CA, respectively. As shown in the figures, the time to drop the conductivity values to about zero, which indicates the consumption of all $\mathrm{Ca}^{2+}$ ions and completion of the $\mathrm{CaCO}_{3}$ crystallization, increased in the presence of immobilized-CA in the solution. As shown in Figure $2 c$, the time to drop the conductivity value to about zero was steadily increasing with the amount of immobilized-CA when $0.25 \mathrm{~g}$ of biocatalytic-PU foam was used. As shown in Figure 2d, the time to drop the conductivity value to about zero was decreasing with the amount of biocatalytic-PU foam and, therefore, the amount of immobilized-CA. The drop in conductivity values was very fast and linear at some cases and fluctuated in others, indicating that the $\mathrm{CO}_{2}$ dissolution and $\mathrm{CaCO}_{3}$ crystallization were affected by the immobilized-CA. Therefore, it is clear from these findings that the immobilized-CA is active in high alkaline solution at $\mathrm{pH} 12.5$.

We have shown that the measured conductivity values are linearly related to the $\left[\mathrm{Ca}(\mathrm{OH})_{2}\right]$ concentration up to its solubility limit of $20 \mathrm{mM}^{6,42}$

$$
\text { Conductivity }=0.4268\left[\mathrm{Ca}(\mathrm{OH})_{2}\right]
$$

where conductivity is in $\mathrm{mS} / \mathrm{cm}$ and $\left[\mathrm{Ca}(\mathrm{OH})_{2}\right]$ is in $\mathrm{mM}$, which is also in very good agreement with the literature. ${ }^{49,50}$ The crystallization rate, therefore, can be obtained from the change in conductivity with time up to its solubility limit.

$$
-\mathrm{d}(\text { Cond. }) / \mathrm{d} t=\text { Rate }
$$


Because $1 \mathrm{~mol}$ of $\mathrm{Ca}^{2+}$ ion was produced when $1 \mathrm{~mol}$ of $\mathrm{Ca}(\mathrm{OH})_{2}$ dissolved, and $1 \mathrm{~mol}$ of $\mathrm{CaCO}_{3}$ was produced when 1 mol of $\mathrm{Ca}^{2+}$ was consumed, the $\mathrm{Ca}^{2+}$ consumption rate and $\mathrm{CaCO}_{3}$ crystallization rate can be estimated from the linearity between conductivity and $\left[\mathrm{Ca}(\mathrm{OH})_{2}\right]$ concentrations. Also, 1 mol of $\mathrm{CO}_{2}$ was consumed for $1 \mathrm{~mol}$ of $\mathrm{Ca}(\mathrm{OH})_{2}$ spent; the $\mathrm{CO}_{2}$ dissolution rate can also be related to the $\mathrm{CaCO}_{3}$ crystallization rate.

$$
\mathrm{Ca}(\mathrm{OH})_{2}+\mathrm{CO}_{2} \rightarrow \mathrm{CaCO}_{3}+\mathrm{H}_{2} \mathrm{O}
$$

Figure 3 shows the $\mathrm{CaCO}_{3}$ crystallization rates obtained from the conductivity change in the presence of bare-PU foam, freeCA, $0.25 \mathrm{~g}$ of PU foam containing different amounts of immobilized-CA, and different amounts of PU foam with the same amount of immobilized-CA. The $\mathrm{CO}_{2}$ dissolution rate, the $\mathrm{Ca}^{2+}$ consumption rate, or the $\mathrm{CaCO}_{3}$ crystallization rate can be obtained from the change in conductivity. Here, the lines are the average of 2 data points for the rates. As shown in Figure 3a, as soon as $\mathrm{CO}_{2}$ was introduced to the top of the minireactor, it dissolved in the solution with small variations in rate. The crystallization rate was almost the same for each barePU foam sample. The rate slightly decreased for the late stage of crystallization, for which $\mathrm{pH}$ decreased, the $\mathrm{Ca}^{2+}$ ion concentration decreased, and other ionic species as a result of $\mathrm{CO}_{2}$ dissolution appeared in the suspension. After the consumption of all $\mathrm{Ca}^{2+}$ ions, the rates were seen to increase again due to dissolution of some solid- $\mathrm{CaCO}_{3}$ particles in the suspension. ${ }^{6}$ Similar behaviors were observed for the free-CA as shown in Figure $3 \mathrm{~b}$. However, the rate was lower for some freeenzyme concentrations $(0.09$ and $0.23 \mu \mathrm{M})$ at the early stages of crystallization and recovered at the late stages. This is important because it indicates that the free-CA was active initially and lost its activity in less than $6 \mathrm{~min}$ in the alkaline solution. The $\mathrm{Ca}^{2+}$ ion consumption rates were relatively lower in the presence of immobilized-CA as shown in Figure 3c,d, indicating that the immobilized-CA was significantly active in $\mathrm{Ca}(\mathrm{OH})_{2}$ solution and delayed the $\mathrm{CaCO}_{3}$ crystallization. As shown in Figure $3 c$, the $\mathrm{CaCO}_{3}$ crystallization rate, $\mathrm{Ca}^{2+}$ ion consumption rate, or $\mathrm{CO}_{2}$ dissolution rate was higher for $0.25 \mathrm{~g}$ of bare-PU foam; however, the rate decreased significantly in the presence of immobilized-CA. The rate was getting lower with the amount of immobilized-CA within the biocatalytic PU foams. The $\mathrm{CaCO}_{3}$ crystallization rate increased when the amount of biocatalytic-PU foam increased as shown in Figure 3d. It was understood that, while the dissolved $\mathrm{CO}_{2}$ enhanced the $\mathrm{CaCO}_{3}$ crystallization, the immobilized-CA hindered the $\mathrm{CaCO}_{3}$ crystallization at high alkaline condition. Therefore, a fluctuation in rate was seen through the progress of crystallization, and at the end, the crystallization proceeded for completion.

It seems that immobilized-CA competed with the dissolved $\mathrm{CO}_{2}$ for the $\mathrm{CaCO}_{3}$ crystallization. Considering the ionic speciation, a flowchart was proposed as shown in Figure 4 to figure out the role of ionic species and $\mathrm{CA}$ enzyme on $\mathrm{CaCO}_{3}$ crystallization. When $\mathrm{Ca}(\mathrm{OH})_{2}$ dissolved, $\mathrm{Ca}^{2+}, \mathrm{OH}^{-}$, and $\mathrm{Ca}(\mathrm{OH})^{+}$ions form in the solution. ${ }^{51}$

$$
\begin{aligned}
& \mathrm{Ca}(\mathrm{OH})_{2}(\mathrm{aq}) \rightleftharpoons \mathrm{Ca}(\mathrm{OH})^{+}+\mathrm{OH}^{-} \\
& \mathrm{Ca}(\mathrm{OH})^{+} \rightleftharpoons \mathrm{Ca}^{2+}+\mathrm{OH}^{-}
\end{aligned}
$$

When the $\mathrm{CO}_{2}$ gas was introduced into the aqueous phase, a number of transformations occur at the gas-liquid interphase

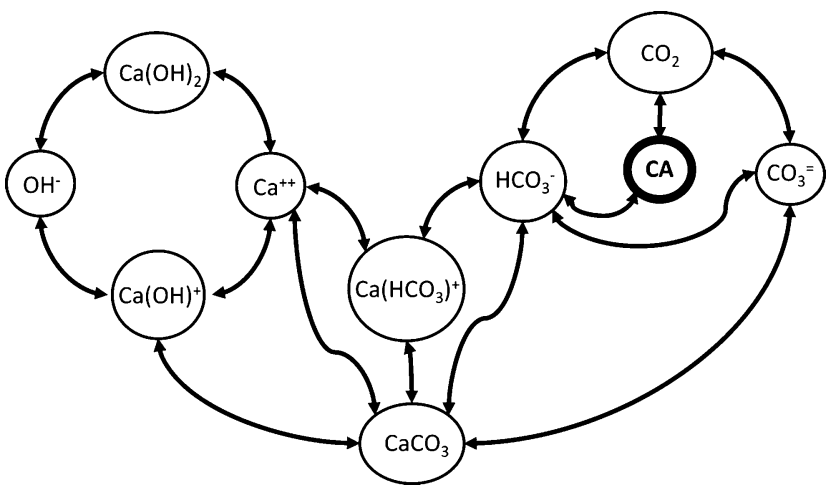

Figure 4. A flowchart to show the ionic species and CA involved in $\mathrm{CaCO}_{3}$ crystallization.

such as dissolution in aqueous phase, hydration by water, ionization, and carbonate formation. ${ }^{12}$

$$
\begin{aligned}
& \mathrm{CO}_{2}(\mathrm{~g}) \rightleftharpoons \mathrm{CO}_{2}(\mathrm{aq}) \\
& \mathrm{CO}_{2}(\mathrm{aq})+\mathrm{H}_{2} \mathrm{O} \rightleftharpoons \mathrm{H}_{2} \mathrm{CO}_{3} \\
& \mathrm{H}_{2} \mathrm{CO}_{3} \rightleftharpoons \mathrm{HCO}_{3}{ }^{-}+\mathrm{H}^{+} \\
& \mathrm{HCO}_{3}{ }^{-} \rightleftharpoons \mathrm{CO}_{3}{ }^{2-}+\mathrm{H}^{+}
\end{aligned}
$$

When the $\mathrm{pH}$ is higher than 10 , the carbonate formation becomes dominant by the $\mathrm{OH}^{-}$ions. ${ }^{13}$

$$
\mathrm{CO}_{2}(\mathrm{aq})+\mathrm{OH}^{-} \rightleftharpoons \mathrm{CO}_{3}{ }^{2-}+\mathrm{H}^{+}
$$

In the presence of $\mathrm{Ca}^{2+}$ ions, additional ions, clusters, and nanoparticles could form in the carbonate buffer. ${ }^{51-53}$

$$
\begin{aligned}
& \mathrm{Ca}^{2+}+\mathrm{HCO}_{3}^{-} \rightleftharpoons \mathrm{CaHCO}_{3}^{+} \\
& \mathrm{CaHCO}_{3}^{+} \rightleftharpoons \mathrm{CaCO}_{3}(\mathrm{aq})+\mathrm{H}^{+} \\
& \mathrm{Ca}^{2+}+\mathrm{CO}_{3}{ }^{2-} \rightleftharpoons \mathrm{CaCO}_{3}
\end{aligned}
$$

The complex formation of $\mathrm{Ca}^{2+}$ ions consumes $\mathrm{OH}^{-}$and $\mathrm{HCO}_{3}{ }^{-}$ions to form $\mathrm{Ca}(\mathrm{OH})^{+}$and $\mathrm{CaHCO}_{3}{ }^{+}$species. Here, the solubility of $\mathrm{CaCO}_{3}$ is about $0.1 \mathrm{mM}^{42}$ and all the species eventually end up in the solid- $\mathrm{CaCO}_{3}$ particles controlled by the three rate-determining processes. ${ }^{54,55}$

Carbonic anhydrase was expected to accelerate the $\mathrm{CO}_{2}$ hydration to form $\mathrm{HCO}_{3}{ }^{-}$and increase the rate for $\mathrm{CaCO}_{3}$ crystallization. In the presence of $\mathrm{CA}$, the $\mathrm{CO}_{2}$ hydration is initiated by the nucleophilic attack on the carbon atom of $\mathrm{CO}_{2}$, by the zinc-bound $\mathrm{OH}^{-}$, to produce $\mathrm{HCO}_{3}^{-}$, which is then displaced from the zinc by a water molecule. ${ }^{46}$

$$
\begin{aligned}
& \mathrm{CA}-\mathrm{Zn}-\mathrm{H}_{2} \mathrm{O} \rightleftharpoons \mathrm{CA}-\mathrm{Zn}-\mathrm{OH}^{-}+\mathrm{H}^{+} \\
& \mathrm{CA}-\mathrm{Zn}-\mathrm{OH}^{-}+\mathrm{CO}_{2} \rightleftharpoons \mathrm{CA}-\mathrm{Zn}-\mathrm{HCO}_{3}{ }^{-} \\
& \mathrm{CA}^{-} \mathrm{Zn}-\mathrm{HCO}_{3}{ }^{-} \rightleftharpoons \mathrm{CA}-\mathrm{Zn}-\mathrm{H}_{2} \mathrm{O}+\mathrm{HCO}_{3}^{-}
\end{aligned}
$$

Here, the first step is the activation of CA and it is expected that $\mathrm{CA}$ is always active in alkaline solution. When the concentration of dissolved $\mathrm{CO}_{2}(\mathrm{aq})$ is higher, the $\mathrm{CA}$ is expected to catalyze the hydration of $\mathrm{CO}_{2}$ to form more $\mathrm{HCO}_{3}{ }^{-}$. This is the usual studies in biocatalytic $\mathrm{CaCO}_{3}$ crystallization at lower $\mathrm{pHs}$ as generally reported in the literature. ${ }^{12,13,34,54,56,57}$ However, when $\mathrm{CA}$ is active at higher $\mathrm{pHs}$ and the $\mathrm{HCO}_{3}{ }^{-}$ion concentration increases rapidly, the 

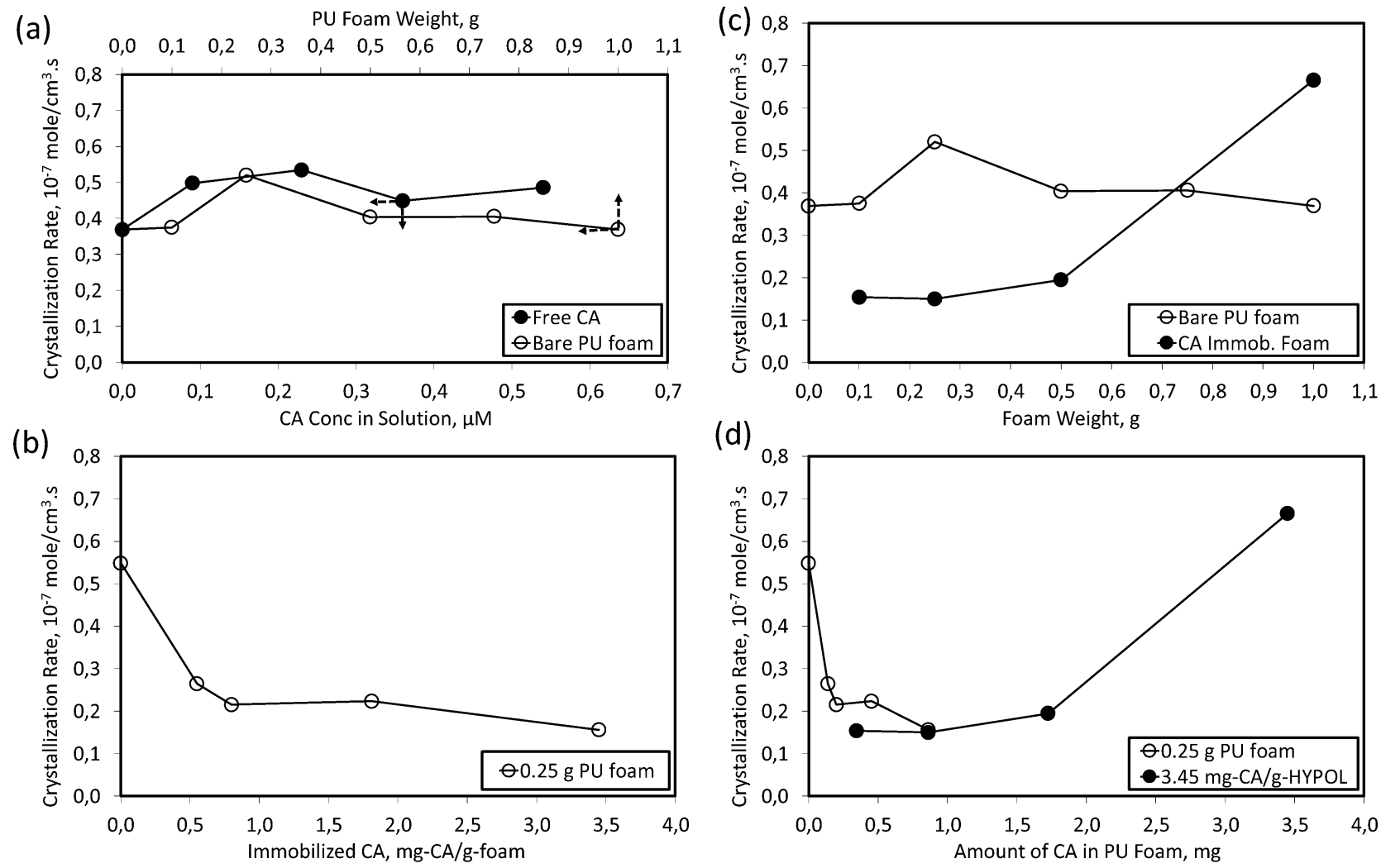

Figure 5. Comparison of maximum crystallization rates achieved for (a) bare-PU foam and free-CA, (b) $0.25 \mathrm{~g}$ of PU foam containing different amounts of CA immobilized, (c) different amounts of bare foam and CA-immobilized PU foam, (d) calculated different amounts of immobilized-CA in PU foam.

CA now operates in the opposite direction and dehydrates the $\mathrm{HCO}_{3}{ }^{-}$ions to produce $\mathrm{CO}_{2}{ }^{46}$ The $\mathrm{CO}_{2}(\mathrm{aq})$ can then follow other paths as shown in Figure 4 and end up in $\mathrm{CaCO}_{3}$ crystallization. However, this mechanism decreases the crystallization rate as occurred in our study.

It can be noted that the conductivity for $20 \mathrm{mM} \mathrm{Ca}(\mathrm{OH})_{2}$ solution is about $8.6 \mathrm{mS} / \mathrm{cm}$. This conductivity value decreases to about zero during $\mathrm{CaCO}_{3}$ crystallization. About zero values of conductivity in the presence of solid- $\mathrm{CaCO}_{3}$ particles indicate that solid nano- $\mathrm{CaCO}_{3}$ does not affect the conductivity reading. When the $\mathrm{CaCO}_{3}$ suspension was fully saturated with $\mathrm{CO}_{2}$, the conductivity value increases up to about $1.9 \mathrm{mS} / \mathrm{cm}$, and this conductivity value was attributed to $\mathrm{Ca}^{2+}$ ion concentration considering the concentrations of the ion pairs negligible. ${ }^{55}$ Therefore, solid-nano- $\mathrm{CaCO}_{3}$ particles affect neither the conductivity reading nor the estimation of $\mathrm{CaCO}_{3}$ crystallization rates in $\mathrm{Ca}(\mathrm{OH})_{2}$ solution, and this technique can be employed in biocatalytic enzyme activity determination at alkaline conditions.

Figure 5 compares the maximum $\mathrm{CaCO}_{3}$ crystallization rates achieved in $\mathrm{Ca}(\mathrm{OH})_{2}$ solution. As shown in Figure 5a, the $\mathrm{CaCO}_{3}$ crystallization rate was about $0.37 \times 10^{-7} \mathrm{~mol} / \mathrm{cm}^{3} \cdot \mathrm{s}$ in $\mathrm{Ca}(\mathrm{OH})_{2}$ solution as the control experiment and this rate remained almost unchanged for different amounts of bare-PU foam added into the solution. This value is very much comparable with the $\mathrm{CO}_{2}$ absorption rate of $3 \times 10^{-7} \mathrm{~mol} / \mathrm{cm}^{3}$. $\mathrm{s}$ in $\mathrm{Ca}(\mathrm{OH})_{2}$ solution reported by Juvekar and Sharma ${ }^{58}$ in 1973. The difference is due to the surface area to the mass transfer, and it seems that Juvekar and Sharma ${ }^{58}$ used almost 8.2 times bigger gas-solid interface area in their reactor. The $\mathrm{CaCO}_{3}$ crystallization rate was about $0.49 \times 10^{-7} \mathrm{~mol} / \mathrm{cm}^{3} \cdot \mathrm{s}$ for
free-CA in $\mathrm{Ca}(\mathrm{OH})_{2}$ solution, and this rate remained almost unchanged for each free-CA concentration. The lower crystallization rates obtained for the bare-PU foam could be due to the absorption of solution within the foam because the foam itself absorbs water of about 13 times of its weight (unpublished result).

Figure $5 \mathrm{~b}$ shows the $\mathrm{CaCO}_{3}$ crystallization rates obtained in the presence of $0.25 \mathrm{~g}$ of $\mathrm{PU}$ foam containing different amounts of immobilized-CA. As shown in the figure, the $\mathrm{CaCO}_{3}$ crystallization rate was about $0.52 \times 10^{-7} \mathrm{~mol} / \mathrm{cm}^{3} \cdot \mathrm{s}$ for 0.25 $\mathrm{g}$ of bare-PU foam and this rate decreased to about $0.26 \times 10^{-7}$ $\mathrm{mol} / \mathrm{cm}^{3} \cdot \mathrm{s}$ when immobilized-CA was included in PU foams. The crystallization rate was seen to decrease further as the amount of immobilized-CA increased, indicating that the biocatalytic activity in the biocatalytic-PU foams increases with the amount of immobilized-CA.

Figure $5 \mathrm{c}$ compares the $\mathrm{CaCO}_{3}$ crystallization rates obtained for the same amount of bare foam and biocatalytic-PU foams. As shown in the figure, the crystallization rate was about $0.37 \times$ $10^{-7} \mathrm{~mol} / \mathrm{cm}^{3} \cdot \mathrm{s}$ for bare-PU foams and it remained almost unchanged with its different amounts. There is a significant decrease in crystallization rate of about $0.16 \times 10^{-7} \mathrm{~mol} / \mathrm{cm}^{3} \cdot \mathrm{s}$ when CA-immobilized PU foams were added into the $\mathrm{Ca}(\mathrm{OH})_{2}$ solution. When the amount of biocatalytic-PU foams was increased, the $\mathrm{CaCO}_{3}$ crystallization rate became higher at a slower pace at low biocatalytic foam amounts and at a faster pace at higher biocatalytic foam amounts exceeding the rates for the bare-PU foams. The crystallization rate of about $0.67 \times 10^{-7} \mathrm{~mol} / \mathrm{cm}^{3} \cdot \mathrm{s}$ was obtained for $1.0 \mathrm{~g}$ of biocatalyticPU foam. As can be seen in the figure, while lower amounts of 
Table 1. $\mathrm{CaCO}_{3}$ Crystallization Rates in the Presence of Bare-PU Foam, Free-CA, and Immobilized-CA

$\begin{array}{ccccc}\mathrm{Ca}(\mathrm{OH})_{2} & \text { PU-foam } & \text { free-CA } & \text { immob.-CA } & \mathrm{CaCO}_{3} \text { crystallization rate, } 10^{-8} \mathrm{~mol} / \mathrm{cm}^{3} \cdot \mathrm{s} \\ + & - & - & - & 3.7 \\ + & + & - & - & 4.0 \\ + & - & - & \text { low }(0.86 \mathrm{mg}) & 4.9 \\ + & - & - & \text { high }(3.45 \mathrm{mg}) & 1.6 \\ \end{array}$

immobilized-CA decelerated the $\mathrm{CaCO}_{3}$ crystallization, higher amounts of immobilized-CA accelerated it.

The biocatalytic activity of immobilized-CA was compared with respect to the amount of immobilized enzyme in biocatalytic-PU foams. The immobilized-CA amount was calculated accounting for the amount of HYPOL and the amount of CA added originally for immobilization as described in the experimental section. Figure $5 \mathrm{~d}$ shows the $\mathrm{CaCO}_{3}$ crystallization rates for different amounts of immobilized-CA within the biocatalytic-PU foams. As shown in the figure, when a constant amount of biocatalytic-PU foam, $0.25 \mathrm{~g}$, was used, the immobilized-CA was active and decreased the $\mathrm{CaCO}_{3}$ crystallization rate. When the biocatalytic foam amount, and thus the immobilized-CA, was increased, again, the immobilized-CA was active and decreased the crystallization rate at low immobilized-CA amounts. However, there was an increasing trend in the $\mathrm{CaCO}_{3}$ crystallization rate with the immobilized$\mathrm{CA}$ amount. It seems that there is a $\mathrm{U}$-shape in $\mathrm{CaCO}_{3}$ crystallization rate with the amount of immobilized-CA, which we believe determines the accelerating or decelerating activity of the immobilized-CA on the $\mathrm{CaCO}_{3}$ crystallization.

Information for the accelerating or decelerating activity of the immobilized-CA may be withdrawn by comparing the $\mathrm{CaCO}_{3}$ crystallization rates summarized in Table 1 and analyzing the flowchart in Figure 4. The $\mathrm{CaCO}_{3}$ crystallization rate was measured about $3.7 \times 10^{-8} \mathrm{~mol} / \mathrm{cm}^{3} \cdot \mathrm{s}$ in $\mathrm{Ca}(\mathrm{OH})_{2}$ solution. In the absence of $\mathrm{CA}, \mathrm{CO}_{2}$ dissolves and crystallizes in the $\mathrm{Ca}(\mathrm{OH})_{2}$ solution. It was known that this process is controlled by the $\mathrm{CO}_{2}$ hydration rate and mass transfer rate for the crystal growth. ${ }^{54,55}$ In the presence of bare-PU foam, the rate was about $4.0 \times 10^{-8} \mathrm{~mol} / \mathrm{cm}^{3} \cdot \mathrm{s}$, which was slightly higher than that for the control. Bare-PU foams may help nucleation of the $\mathrm{CaCO}_{3}$ crystals; therefore, an increase occurred in crystallization. ${ }^{59}$ In the presence of free- $\mathrm{CA}$, the $\mathrm{CaCO}_{3}$ crystallization rate was about $4.9 \times 10^{-8} \mathrm{~mol} / \mathrm{cm}^{3} \cdot \mathrm{s}$, which is almost $32 \%$ higher than that for the control and about $22 \%$ higher than that for the bare-PU foam. It was claimed in the literature that one molecule of $\mathrm{CO}_{2}$ should be released for each $\mathrm{CaCO}_{3}$ molecule deposited on the surface and 2 molecules of $\mathrm{HCO}_{3}{ }^{-}$were consumed, and free-CA enzyme was employed to show the increase in the crystallization rate. ${ }^{54,60}$ This idea was debated by Zhang and Grattoni, ${ }^{61}$ indicating that CA could have reduced the energy barrier of forming new nuclei of $\mathrm{CaCO}_{3}$, which provided additional sites for crystallization. The authors ${ }^{62}$ responded that their claim was valid. In this case, a net $1 \mathrm{~mol}$ of $\mathrm{CO}_{2}$ was consumed for $1 \mathrm{~mol}$ of $\mathrm{CaCO}_{3}$ produced, which does not violate the stoichiometry of the crystallization. Consequently, as shown in Figure 4, not only the $\mathrm{CO}_{3}{ }^{2-}$ ion concentration but also the $\mathrm{HCO}_{3}{ }^{-}$ion and other complex ions in the solution such as $\mathrm{Ca}(\mathrm{OH})^{+}$and $\mathrm{CaHCO}_{3}{ }^{+}$play a role in $\mathrm{CaCO}_{3}$ crystallization. ${ }^{49,51,54}$ Our results indicated that there was a $32 \%$ increase in the $\mathrm{CaCO}_{3}$ crystallization rate in the presence of free-CA. However, we did not see an increasing trend with free-CA concentrations. Therefore, we conclude that the free-CA may not be active in alkaline solution and serves as a template in the solution for forming new nuclei of $\mathrm{CaCO}_{3}$ to increase the crystallization rate, in agreement with the literature. ${ }^{54,55,59}$ In the presence of immobilized-CA, the $\mathrm{CaCO}_{3}$ crystallization rate was amount dependent. As shown in Table 1, when the amount of immobilized-CA is low, 0.86 $\mathrm{mg}$, the $\mathrm{CaCO}_{3}$ crystallization rate was about $1.6 \times 10^{-8} \mathrm{~mol} /$ $\mathrm{cm}^{3} \cdot \mathrm{s}$, and when the amount of immobilized-CA is high, 3.45 $\mathrm{mg}$, the $\mathrm{CaCO}_{3}$ crystallization rate was about $6.7 \times 10^{-8} \mathrm{~mol} /$ $\mathrm{cm}^{3} \cdot \mathrm{s}$. Relatively lower rates were observed for the low amount of immobilized-CA. As shown in Figure 4, $\mathrm{HCO}_{3}{ }^{-}$ion is in the focus. It is clear that the immobilized-CA within the PU foam seems to play a role in $\mathrm{CO}_{2}-\mathrm{HCO}_{3}{ }^{-}$equilibria, resulting in a relative slowdown of the $\mathrm{CaCO}_{3}$ crystallization. When the amount of immobilized-CA is low, it converts $\mathrm{HCO}_{3}{ }^{-}$to $\mathrm{CO}_{2}(\mathrm{aq})$ and reduces its concentration in the solution, which causes deceleration of the crystal growth. When the amount of immobilized-CA is high, the conversion of $\mathrm{HCO}_{3}{ }^{-}$becomes too high so that an increase in the $\mathrm{CO}_{2}(\mathrm{aq})$ concentration will alarm other immobilized-CA at the neighborhood for the increasing substrate, which accelerates the $\mathrm{CaCO}_{3}$ crystal growth. Therefore, a higher immobilized-CA amount is required to accelerate the $\mathrm{CO}_{2}$ hydration and the $\mathrm{CaCO}_{3}$ crystallization in $\mathrm{Ca}(\mathrm{OH})_{2}$ solution.

Figure 6 shows the $\mathrm{CaCO}_{3}$ particles formed on the surface (Figure 6a) and within the pores (Figure $6 \mathrm{~b}$ ) of the PU foam.
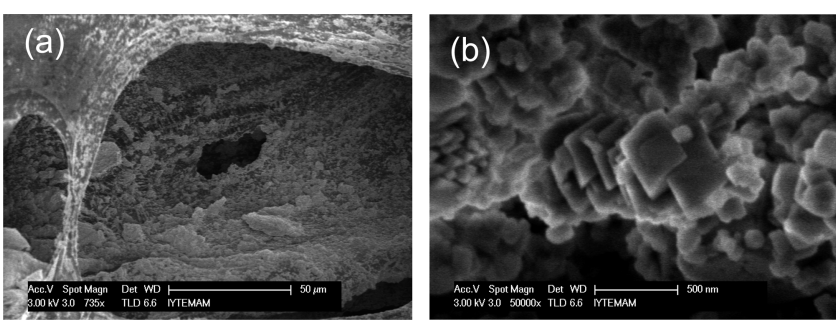

Figure 6. SEM images of precipitated $\mathrm{CaCO}_{3}$ crystals (a) on the surface and (b) within the pore of the PU foam.

Classical crystallization mechanisms claim that the nucleation step is required before crystal growth. ${ }^{63}$ However, novel crystallization mechanisms indicated a prenucleation process in which ions form stable cluster particles. ${ }^{64}$ These clusters are charged particles in equilibrium with their ions, and they can grow or collide to produce $\mathrm{CaCO}_{3}$ nuclei. In a recent study, crystallization on a polymeric template was also revealed. ${ }^{59}$ The nature of the polymeric additives such as $\mathrm{PU}$ foam composed of polar groups may influence the $\mathrm{CaCO}_{3}$ crystallization and nuclei formation ${ }^{31,65}$ It is expected that the ions from $\mathrm{Ca}(\mathrm{OH})_{2}$ solution and newly synthesized clusters as well as nanoparticles would partition within the pores in the PU foam and in the liquid medium. As shown in the figure, the $\mathrm{CaCO}_{3}$ particles were clearly seen precipitated on the surface of the foam. These particles are chainlike cubic and round shaped aggregated nano- 

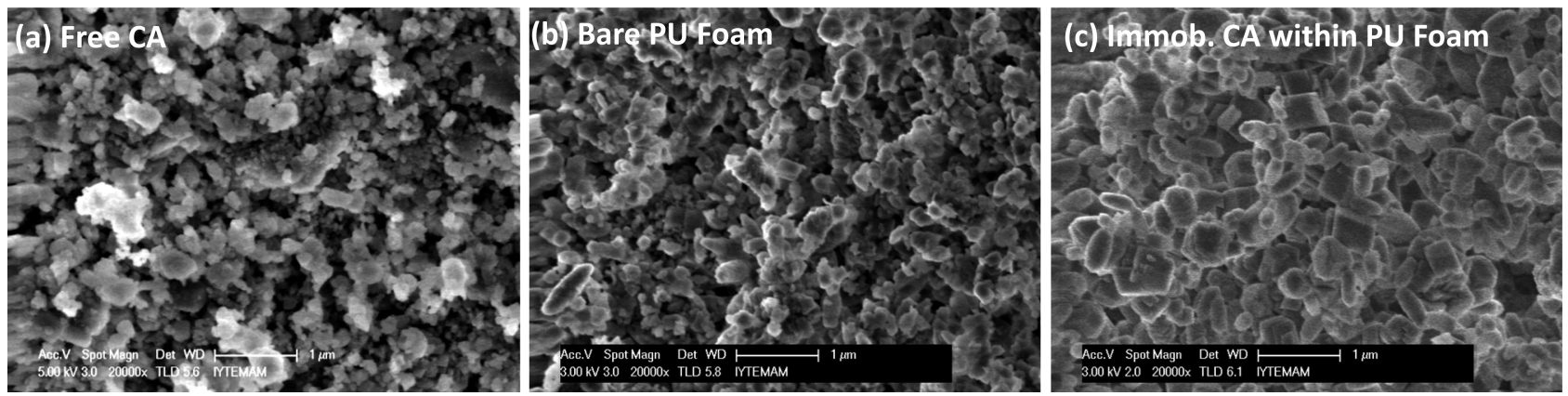

Figure 7. SEM images of $\mathrm{CaCO}_{3}$ particles obtained in the presence of (a) free-CA, (b) bare-PU foam, and (c) immobilized-CA within PU foam.

$\mathrm{CaCO}_{3}$ particles. It is possible that the adsorption of $\mathrm{CaCO}_{3}$ nuclei particles deposit on the polymeric foams. This would create a mass transfer resistance in the biocatalytic foams for substrate and product diffusion. However, it seems that this is not the issue because particles in the PU foam are too small and there is a significant deceleration in the carbonization rate by the immobilized-CA. Otherwise, the crystallization rate would not change or would increase in the presence of biocatalytic polymers at the low CA amount conditions.

Figure 7 shows the SEM images of the produced $\mathrm{CaCO}_{3}$ crystals in the presence of free-CA, bare-PU foam, and immobilized-CA. As can be seen from the figure, the $\mathrm{CaCO}_{3}$ particles produced in the presence of free-CA were generally in round shapes from about 30 to $300 \mathrm{~nm}$ in sizes and highly aggregated. For the bare-PU foam used, chainlike nano- $\mathrm{CaCO}_{3}$ particles were obtained and they were mostly aggregated. When CA-immobilized biocatalytic-PU foam was used, rhombohedral $\mathrm{CaCO}_{3}$ particles were synthesized in round shapes and aggregation seemed to disappear. Therefore, individual nano$\mathrm{CaCO}_{3}$ particles of sizes from about 300 to $500 \mathrm{~nm}$ were obtained in the presence of immobilized CA. These particles were determined to be calcite, as evidenced from the XRD patterns shown in Figure 8. It is clear from the SEM image that

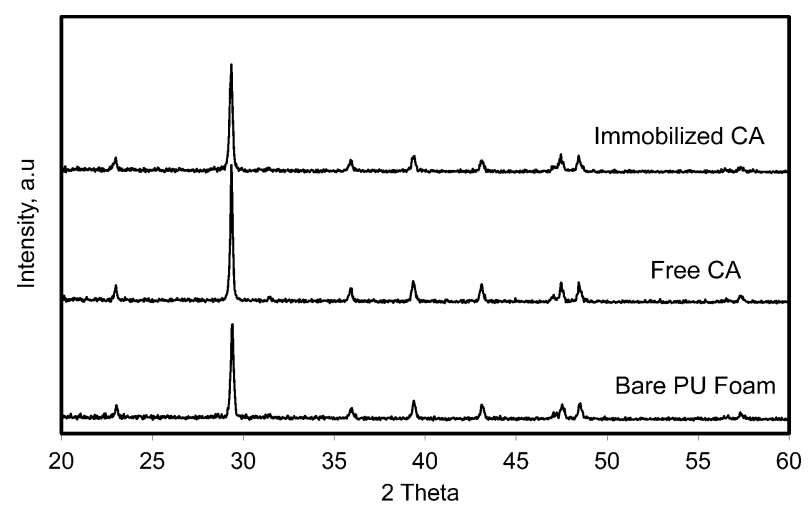

Figure 8. XRD patterns of the precipitated $\mathrm{CaCO}_{3}$ particles obtained for bare-PU foam, free-Ca, and immobilized-CA.

these particles have rough surfaces as if they were subjected to erosion in the solution, indicating that the free-CA acts as a template for $\mathrm{CaCO}_{3}$ crystallization. ${ }^{59}$ The spherical morphology generally refers to the vaterite polymorph of $\mathrm{CaCO}_{3}$ in the chemical method, for which calcium chloride $\left(\mathrm{CaCl}_{2}\right)$ and sodium carbonate $\left(\mathrm{Na}_{2} \mathrm{CO}_{3}\right)$ were used as the source for the precursors. ${ }^{59}$ Interestingly, as evidenced from the XRD patterns for the particles as shown in Figure 8, the round shaped particles obtained in the presence of free-CA were calcite.
Calcite is found generally in cubical shape and the most stable form of $\mathrm{CaCO}_{3}$. Contrary to the cubical morphology, the calcite particles obtained here were in round shapes and composed of aggregated polycrystalline nanoparticles. The diffraction peaks detected by XRD refer to index of a calcite polymorph of $\mathrm{CaCO}_{3}$ (space group: $\left.R_{3} c(167)\right)^{66}$ with the Bragg's reflections which were given in JCPDS files, Card 5586 , the $2 \theta$ value at $29.468^{\circ}$. The sharp diffractions at the $d$ spacings $3.02864,1.91257$, and 1.87567 confirm the presence of the rhombohedral calcite structure in the $\left(\begin{array}{lll}1 & 0 & 4\end{array}\right)$ lattice position for the control experiment. $2 \theta$ values at about $29.4^{\circ}$ and $d$-spacing at about 3.03 indicate the presence of calcite crystals for each sample. The crystals have nearly identical peak positions and narrow peak widths as calcite. No obvious characteristic diffraction peaks of any impurities were detected. The crystal sizes were calculated by the Debye Scherrer equation, and the average crystal size was found to be about 40 $\mathrm{nm} \pm 4.73 \mathrm{~nm}$. In agreement with the SEM images, these aggregates were composed of polycrystalline particles of about $40 \mathrm{~nm}$ in size. If the aggregation would not occur, nanosized calcite particles could be produced by using the currently designed experimental setup.

\section{CONCLUSIONS}

A new measurement method was developed to estimate the CA activity immobilized in the polyurethane foam especially in alkaline solution. A minireactor was created within $\mathrm{Ca}(\mathrm{OH})_{2}$ solution, and the $\mathrm{CO}_{2}$ was introduced to its surface in order to control the $\mathrm{CO}_{2}$ injection and the crystallization rates. The $\mathrm{CaCO}_{3}$ crystallization rate was relatively lower for the immobilized-CA at low amounts, and this rate increased when the amount of immobilized-CA was higher. Reproducible results were achieved, producing polycrystalline calcite particles of about $40 \mathrm{~nm}$, which aggregated to form larger particles of about $300 \mathrm{~nm}$. The nanoparticles synthesized in solutions were larger for the immobilized-CA compared to those for the free$\mathrm{CA}$ and bare-PU foam. It was concluded that the free-CA lost is activity in high alkaline solution. The free-CA may serve as a template for forming new nuclei of $\mathrm{CaCO}_{3}$ to increase the crystallization rate. The immobilized-CA within the PU foam was active in high alkaline solution. Immobilized-CA seems to play a role in $\mathrm{CO}_{2}-\mathrm{HCO}_{3}{ }^{-}$equilibria, resulting in a relative slowdown of the $\mathrm{CaCO}_{3}$ crystallization when it is in a low amount. Therefore, a higher immobilized-CA amount is required to accelerate the $\mathrm{CO}_{2}$ hydration and the $\mathrm{CaCO}_{3}$ crystallization rates in $\mathrm{Ca}(\mathrm{OH})_{2}$ solution. The newly developed method can also be employed at other $\mathrm{pH}$ conditions. 


\section{AUTHOR INFORMATION}

\section{Corresponding Author}

*E-mail: ekremozdemir@iyte.edu.tr. Tel.: +90(232)750 6685. Fax: +90(232)750 6645 .

\section{Notes}

The authors declare no competing financial interest.

\section{ACKNOWLEDGMENTS}

The Scientific and Technological Research Council of Turkey (TUBITAK) is highly appreciated for the research grant with the project number of $110 \mathrm{M} 104$.

\section{REFERENCES}

(1) Huesemann, M. H. Can Advances in Science and Technology Prevent Global Warming? A Critical Review of Limitations and Challenges. Mitigation Adapt. Strategies Global Change 2006, 11, 539577.

(2) Reichle, D.; Houghton, J.; Kane, B.; Ekmann, J. Carbon Sequestration: Research and Development; U.S. DOE Report; U.S. DOE: Washington, DC, 1999.

(3) Gentzis, T. Subsurface sequestration of carbon dioxide- an overview from an Alberta (Canada) perspective. Int. J. Coal Geol. 2000, 43, 287-305.

(4) Abadie, L. M.; Chamorro, J. M. European $\mathrm{CO}_{2}$ prices and carbon capture investments. Energy Economics 2008, 30, 2992-3015.

(5) McCoy, S. T.; Rubin, E. S. An engineering-economic model of pipeline transport of $\mathrm{CO}_{2}$ with application to carbon capture and storage. Int. J. Greenhouse Gas Control 2008, 2, 219-229.

(6) Ulkeryildiz, E.; Kilic, S.; Ozdemir, E. Rice-like hollow nano$\mathrm{CaCO}_{3}$ synthesis. J. Cryst. Growth 2016, 450, 174-180.

(7) Wang, L.; Sondi, I.; Matijevic, E. Preparation of uniform NeedleLike Aragonite Particles by Homogenous Precipitation. J. Colloid Interface Sci. 1999, 218, 545-553.

(8) Wu, W.; He, T.; Chen, J.-f.; Zhang, W.; Chen, Y. Study on In Situ Preparation of Nano Calcium Carbonate/PMMA Composite Particles. Mater. Lett. 2006, 60, 2410-2415.

(9) Dreybrodt, W.; Lauckner, J.; Zaihua, L.; Svensson, U.; Buhmann, D. The Kinetics of the Reaction $\mathrm{CO}_{2}+\mathrm{H}_{2} \mathrm{O}->\mathrm{H}^{+}+\mathrm{HCO}_{3}{ }^{-}$as One of the Rate Limiting Steps for the Dissolution of Calcite in the System $\mathrm{H}_{2} \mathrm{O}-\mathrm{CO}_{2}-\mathrm{CaCO}_{3}$. Geochim. Cosmochim. Acta 1996, 60 (18), 33753381 .

(10) Bond, G. M.; Stringer, J.; Brandvold, D. K.; Medina, M. G.; Simsek, F. A.; Egeland, G. Development of integrated system for biomimetic $\mathrm{CO}_{2}$ sequestration using the enzyme carbonic anhydrase. Energy Fuels 2001, 15, 309-316.

(11) Liu, N.; Bond, G. M.; Abel, A.; McPherson, B. J.; Stringer, J. Biomimetic sequestration of $\mathrm{CO}_{2}$ in carbonate form: Role of produced waters and other brines. Fuel Process. Technol. 2005, 86 (14-15), $1615-1625$.

(12) Mirjafari, P.; Asghari, K.; Mahinpey, N. Investigating the application of enzyme carbonic anhydrase for $\mathrm{CO}_{2}$ sequestration purposes. Ind. Eng. Chem. Res. 2007, 46 (3), 921-926.

(13) Bond, G. M.; Stringer, J.; Brandvold, D. K.; Simsek, F. A. Medina, M. G.; Egeland, G. Development of integrated system for biomimetic $\mathrm{CO}_{2}$ sequestration using the enzyme carbonic anhydrase. Energy Fuels 2001, 15 (2), 309-316.

(14) Sharma, A.; Bhattacharya, A. Enhanced biomimetic sequestration of $\mathrm{CO}_{2}$ into $\mathrm{CaCO}_{3}$ using purified carbonic anhydrase from indigenous bacterial strains. J. Mol. Catal. B: Enzym. 2010, 67 (1-2), $122-128$.

(15) Favre, N.; Christ, M. L.; Pierre, A. C. Biocatalytic capture of $\mathrm{CO}_{2}$ with carbonic anhydrase and its transformation to solid carbonate. J. Mol. Catal. B: Enzym. 2009, 60 (3-4), 163-170.

(16) Li, L.; Hao, D.; Fu, M. Process and apparatus for $\mathrm{CO}_{2}$ capture and sequestration with immobilised carbonic anhydrase. Mater. Technol. 2014, 29 (A1), A44-A47.
(17) Li, W.; Chen, W. S.; Zhou, P. P.; Cao, L.; Yu, L. J. Influence of initial $\mathrm{pH}$ on the precipitation and crystal morphology of calcium carbonate induced by microbial carbonic anhydrase. Colloids Surf., B 2013, 102, 281-287.

(18) Li, W.; Chen, W. S.; Zhou, P. P.; Yu, L. J. Influence of enzyme concentration on bio-sequestration of $\mathrm{CO}_{2}$ in carbonate form using bacterial carbonic anhydrase. Chem. Eng. J. 2013, 232, 149-156.

(19) Li, W.; Chen, W. S.; Zhou, P. P.; Zhu, S. L.; Yu, L. J. Influence of initial calcium ion concentration on the precipitation and crystal morphology of calcium carbonate induced by bacterial carbonic anhydrase. Chem. Eng. J. 2013, 218, 65-72.

(20) Li, W.; Liu, L. P.; Chen, W. S.; Yu, L. J.; Li, W. B.; Yu, H. Z. Calcium carbonate precipitation and crystal morphology induced by microbial carbonic anhydrase and other biological factors. Process Biochem. 2010, 45 (6), 1017-1021.

(21) Drevon, G. F.; Urbanke, C.; Russell, A. J. Enzyme-Containing Michael-Adduct-Based Coatings. Biomacromolecules 2003, 4, 675-682.

(22) Badjić, J. D.; Kostic, N. M. Effect of Encapsulation in Sol-Gel Silica Glass on Esterase Activity, Conformational Stability, and Unfolding of Bovine Carboniic Anhydrase II. Chem. Mater. 1999, $11,3671-3679$.

(23) Cheng, L.-H.; Zhang, L.; Chen, H.-L.; Gao, C.-J. Hollow fiber contained hydrogel-CA membrane contactor for carbon dioxide removal from the enclosed spaces. J. Membr. Sci. 2008, 324, 33-43.

(24) Hosseinkhani, S.; Nemat-Gorgani, M. Partial unfolding of carbonic anhydrase provides a method for its immobilization on hydrophobic adsorbents and protects it against irreversible thermoinactivation. Enzyme Microb. Technol. 2003, 33 (2-3), 179-184.

(25) Romaškevič, T.; Budrienė, S.; Pielichowski, K.; Pielichowski, J. Application of polyurethane-based materials for immobilization of enzymes and cells: a review. Chemija 2006, 17 (4), 74-89.

(26) Bakker, M.; van de Velde, F.; van Rantwijk, F.; Sheldon, R. A. Highly Efficient Immobilization of Glycosylated Enzymes into Polyurethane Foams. Biotechnol. Bioeng. 2000, 70 (3), 342-348.

(27) LeJeune, K. E.; Mesiano, A. J.; Bower, S. B.; Grimsley, J. K.; Wild, J. R.; Russell, A. J. Dramatically Stabilized PhosphotriesterasePolymers for Nerve Agent Degradation. Biotechnol. Bioeng. 1997, 54 (2), 105-114.

(28) LeJeune, K. E.; Russell, A. J. Covalent Binding of a Nerve Agent Hydrolyzing Enzyme within Polyurethane Foams. Biotechnol. Bioeng. 1996, 51, 450-457.

(29) Wood, L. L. A hydrophilic Polyurethane Foam System. J. Cell. Plast. 1976, 12, 285-288.

(30) Kanbar, B.; Ozdemir, E. Thermal Stability of Carbonic Anhydrase Immobilized Within Polyurethane Foam. Biotechnol. Prog. 2010, 26 (5), 1474-1480.

(31) Ozdemir, E. Biomimetic $\mathrm{CO}_{2}$ Sequestration: 1. Immobilization of Carbonic Anhydrase within Polyurethane Foam. Energy Fuels 2009, 23, 5725-5730.

(32) Migliardini, F.; De Luca, V.; Carginale, V.; Rossi, M.; Corbo, P.; Supuran, C. T.; Capasso, C. Biomimetic $\mathrm{CO}_{2}$ capture using a highly thermostable bacterial alpha-carbonic anhydrase immobilized on a polyurethane foam. J. Enzyme Inhib. Med. Chem. 2014, 29 (1), 146150.

(33) Vinoba, M.; Bhagiyalakshmi, M.; Jeong, S. K.; Yoon, Y. I.; Nam, S. C. Immobilization of carbonic anhydrase on spherical SBA-15 for hydration and sequestration of $\mathrm{CO}_{2}$. Colloids Surf., B 2012, 90, 91-96.

(34) Zhang, S. H.; Zhang, Z. H.; Lu, Y. Q.; Rostam-Abadi, M.; Jones, A. Activity and stability of immobilized carbonic anhydrase for promoting $\mathrm{CO}_{2}$ absorption into a carbonate solution for postcombustion $\mathrm{CO}_{2}$ capture. Bioresour. Technol. 2011, 102 (22), 1019410201.

(35) Zhang, S. H.; Lu, Y. Q.; Ye, X. H. Catalytic behavior of carbonic anhydrase enzyme immobilized onto nonporous silica nanoparticles for enhancing $\mathrm{CO}_{2}$ absorption into a carbonate solution. Int. J. Greenhouse Gas Control 2013, 13, 17-25.

(36) Vinoba, M.; Kim, D. H.; Lim, K. S.; Jeong, S. K.; Lee, S. W.; Alagar, M. Biomimetic Sequestration of $\mathrm{CO}_{2}$ and Reformation to 
$\mathrm{CaCO}_{3}$ Using Bovine Carbonic Anhydrase Immobilized on SBA-15. Energy Fuels 2011, 25, 438-445.

(37) Kanth, B. K.; Jun, S. Y.; Kumari, S.; Pack, S. P. Highly thermostable carbonic anhydrase from Persephonella marina EX-H1: Its expression and characterization for $\mathrm{CO}_{2}$-sequestration applications. Process Biochem. 2014, 49 (12), 2114-2121.

(38) Kim, I. G.; Jo, B. H.; Kang, D. G.; Kim, C. S.; Choi, Y. S.; Cha, $\mathrm{H}$. J. Biomineralization-based conversion of carbon dioxide to calcium carbonate using recombinant carbonic anhydrase. Chemosphere 2012, 87 (10), 1091-1096.

(39) da Costa Ores, J.; Sala, L.; Cerveira, G. P.; Kalil, S. J. Purification of carbonic anhydrase from bovine erythrocytes and its application in the enzymic capture of carbon dioxide. Chemosphere 2012, 88 (2), 255-259.

(40) Ramanan, R.; Kannan, K.; Vinayagamoorthy, N.; Ramkumar, K.; Sivanesan, S.; Chakrabarti, T. Purification and characterization of a novel plant-type carbonic anhydrase from Bacillus subtilis. Biotechnol. Bioprocess Eng. 2009, 14 (1), 32-37.

(41) Ozdemir, E.; Morsi, B. I.; Schroeder, K. Importance of volume effects to adsorption isotherms of carbon dioxide on coals. Langmuir 2003, 19 (23), 9764-9773.

(42) Kilic, S.; Toprak, G.; Ozdemir, E. Stability of $\mathrm{CaCO}_{3}$ in $\mathrm{Ca}(\mathrm{OH})_{2}$ solution. Int. J. Miner. Process. 2016, 147, 1-9.

(43) Zhu, Y. L.; Li, W. Y.; Sun, G. Z.; Tang, Q.; Bian, H. B. Enzymatic properties of immobilized carbonic anhydrase and the biocatalyst for promoting $\mathrm{CO}_{2}$ capture in vertical reactor. Int. J. Greenhouse Gas Control 2016, 49, 290-296.

(44) Ramanan, R.; Kannan, K.; Sivanesan, S. D.; Mudliar, S.; Kaur, S.; Tripathi, A. K.; Chakrabarti, T. Bio-sequestration of carbon dioxide using carbonic anhydrase enzyme purified from Citrobacter freundii. World J. Microbiol. Biotechnol. 2009, 25 (6), 981-987.

(45) Auzoux-Bordenave, S.; Fouchereau-Peron, M.; Helleouet, M. N.; Doumenc, D. CGRP regulates the activity of mantle cells and hemocytes in abalone primary cell cultures (Haliotis tuberculata). J. Shellfish Res. 2007, 26 (3), 887-894.

(46) Pierre, A. C. Enzymatic Carbon Dioxide Capture. ISRN Chem. Eng. 2012, 2012, 1-22.

(47) Shekh, A. Y.; Krishnamurthi, K.; Mudliar, S. N.; Yadav, R. R.; Fulke, A. B.; Devi, S. S.; Chakrabarti, T. Recent Advancements in Carbonic Anhydrase-Driven Processes for $\mathrm{CO}_{2}$ Sequestration: Minireview. Crit. Rev. Environ. Sci. Technol. 2012, 42 (14), 1419-1440.

(48) Power, I. M.; Harrison, A. L.; Dipple, G. M. Accelerating Mineral Carbonation Using Carbonic Anhydrase. Environ. Sci. Technol. 2016, 50 (5), 2610-2618.

(49) Burns, J. R.; Jachuck, J. J. Monitoring of $\mathrm{CaCO}_{3}$ production on a spinning disc reactor using conductivity measurements. AIChE J. 2005, 51 (5), 1497-1507.

(50) Lide, D., Ed. CRC Handbook of Chemistry and Physics, 75th ed.; CRC Press: Boca Raton, FL, 1995.

(51) Chibowski, E.; Hotysz, L.; Szczes, A. Time dependent changes in zeta potential of freshly precipitated calcium carbonate. Colloids Surf., A 2003, 222 (1-3), 41-54.

(52) Holysz, L.; Chibowski, E.; Szczes, A. Influence of impurity ions and magnetic field on the properties of freshly precipitated calcium carbonate. Water Res. 2003, 37 (14), 3351-3360.

(53) Moulin, P.; Roques, H. Zeta potential measurement of calcium carbonate. J. Colloid Interface Sci. 2003, 261 (1), 115-126.

(54) Dreybrodt, W.; Eisenlohr, L.; Madry, B.; Ringer, S. Precipitation kinetics of calcite in the system $\mathrm{CaCO}_{3}-\mathrm{H}_{2} \mathrm{O}-\mathrm{CO}_{2}$ : The conversion to $\mathrm{CO}_{2}$ by the slow process $\mathrm{H}^{+}+\mathrm{HCO}_{3}^{-} \rightarrow \mathrm{CO}_{2}+\mathrm{H}_{2} \mathrm{O}$ as a rate limiting step. Geochim. Cosmochim. Acta 1997, 61 (18), 3897-3904.

(55) Dreybrodt, W.; Lauckner, J.; Zaihua, L.; Svensson, U.; Buhmann, D. The kinetics of the reaction $\mathrm{CO}_{2}+\mathrm{H}_{2} \mathrm{O} \rightarrow \mathrm{H}^{+}+$ $\mathrm{HCO}_{3}{ }^{-}$as one of the rate limiting steps for the dissolution of calcite in the system $\mathrm{H}_{2} \mathrm{O}-\mathrm{CO}_{2}-\mathrm{CaCO}_{3}$. Geochim. Cosmochim. Acta 1996, 60 (18), 3375-3381.

(56) Prabhu, C.; Wanjari, S.; Puri, A.; Bhattacharya, A.; Pujari, R.; Yadav, R.; Das, S.; Labhsetwar, N.; Sharma, A.; Satyanarayanan, T.; Rayalu, S. Region-Specific Bacterial Carbonic Anhydrase for
Biomimetic Sequestration of Carbon Dioxide. Energy Fuels 2011, 25 (3), 1327-1332.

(57) Vinoba, M.; Bhagiyalakshmi, M.; Jeong, S. K.; Yoon, Y. I.; Nam, S. C. Capture and Sequestration of $\mathrm{CO}_{2}$ by Human Carbonic Anhydrase Covalently Immobilized onto Amine-Functionalized SBA15. J. Phys. Chem. C 2011, 115 (41), 20209-20216.

(58) Juvekar, V. A.; Sharma, M. M. Absorption of $\mathrm{CO}_{2}$ in a Suspension of Lime. Chem. Eng. Sci. 1973, 28 (3), 825-837.

(59) Pouget, E. M.; Bomans, P. H. H.; Goos, J. A. C. M.; Frederik, P. M.; de With, G.; Sommerdijk, N. A. J. M. The Initial Stages of Template-Controlled $\mathrm{CaCO}_{3}$ Formation Revealed by Cryo-TEM. Science 2009, 323 (5920), 1455-1458.

(60) Liu, Z. H.; Dreybrod, W. Dissolution kinetics of calcium carbonate minerals in $\mathrm{H}_{2} \mathrm{O}-\mathrm{CO}_{2}$ solutions in turbulent flow: The role of the diffusion boundary layer and the slow reaction $\mathrm{H}_{2} \mathrm{O}+\mathrm{CO}_{2} \rightarrow$ $\mathrm{H}^{+}+\mathrm{HCO}_{3}{ }^{-}$. Geochim. Cosmochim. Acta 1997, 61 (14), 2879-2889.

(61) Zhang, Y.; Grattoni, C. Comment on "precipitation kinetics of calicte in the system $\mathrm{CaCO}_{3}-\mathrm{H}_{2} \mathrm{O}-\mathrm{CO}_{2}$ : the conversion to $\mathrm{CO}_{2}$ by the slow process $\mathrm{H}^{+}+\mathrm{HCO}_{3}{ }^{-} \rightarrow \mathrm{CO}_{2}+\mathrm{H}_{2} \mathrm{O}$ as a rate limiting step" by W. Dreybrodt, L. Eisenlohr, B. Madry, and S. Ringer. Geochim. Cosmochim. Acta 1998, 62 (23-24), 3789-3790.

(62) Dreybrodt, W. Reply to the Comment by Y. Zhang and C. A. Grattoni on: "precipitation kinetics of calicte in the system $\mathrm{CaCO}_{3}$ $\mathrm{H}_{2} \mathrm{O}-\mathrm{CO}_{2}$ : the conversion to $\mathrm{CO}_{2}$ by the slow process $\mathrm{H}^{+}+\mathrm{HCO}_{3}^{-}$ $\rightarrow \mathrm{CO}_{2}+\mathrm{H}_{2} \mathrm{O}$ as a rate limiting step" by W. Dreybrodt, L. Eisenlohr, B. Madry, and S. Ringer. Geochim. Cosmochim. Acta 1998, 62 (23-24), 3791-3792.

(63) Xu, A. W.; Ma, Y. R.; Colfen, H. Biomimetic mineralization. J. Mater. Chem. 2007, 17 (5), 415-449.

(64) Gebauer, D.; Volkel, A.; Colfen, H. Stable Prenucleation Calcium Carbonate Clusters. Science 2008, 322 (5909), 1819-1822.

(65) Matahwa, H.; Ramiah, V.; Sanderson, R. D. Calcium carbonate crystallization in the presence of modified polysaccharides and linear polymeric additives. J. Cryst. Growth 2008, 310 (21), 4561-4569.

(66) Guo, H.; Yu, J. G.; Cheng, B. Preparation and formation mechanism of wood-block-like calcite particles. J. Solid State Chem. 2006, 179 (8), 2547-2553. 